\title{
GEJOLAK PASAR DAN BUDAYA SEBAGAI MODERASI PENGARUH ORIENTASI KEWIRAUSAHAAN DAN ORIENTASI PASAR TERHADAP KINERJA PEMASARAN
}

\author{
Ayun Maduwinarti \\ ayunmaduwinarti@yahoo.com
}

\author{
Fakultas Ekonomi Universitas 17 Agustus 1945 Surabaya
}

\begin{abstract}
The objectives of this research were to examine and analyze: (1) the effect of entrepreneurial orientation toward marketing performance, (2) the effect of market orientation toward marketing performance, (3) the effects of market turbulence and culture on the strong/weak impact of entrepreneurial orientation toward marketing performance, (4) the effects of market turbulence and culture on the strong/weak impact of market orientation toward marketing performance. The populations of this study were all "Melati" hotels in East Java, as many as 463 hotels spread across cities/regencies in East Java. The sample units were the "Melati" hotels and the respondents were the owners/managers of "Melati" hotels, as many as 90 people. The samples were determined through two stages: the sample area was determined by using Judgment Sampling and the sample of hotels in each city/region which have been selected was defined by Proportional Area Random Sampling. The data analysis used was PLS (Partial least Square). The research result showed that entrepreneurial orientation did not have a significant effect on marketing performance. It was evident that market orientation was influential to marketing performance. The market turbulence as a moderating variable weakened the influence of entrepreneurial orientation and market orientation toward marketing performance. Culture is obviously a moderating effect on entrepreneurial orientation toward marketing performance. There was a coefficient of positive interaction, therefore, culture as the moderator strengthened the influence of entrepreneurial orientation toward marketing performance.
\end{abstract}

Keywords: entrepreneurial and market orientation, market turbulence, culture, marketing performance.

\section{PENDAHULUAN}

Persaingan industri perhotelan di Jawa Timur dewasa ini sangat ketat. Persaingan yang ketat itu ditandai dengan kian banyaknya jumlah hotel baik hotel berbintang maupun 
hotel melati. Seiring dengan pencanangan tahun 2011 sebagai Tahun Kunjungan Jawa Timur (Visit East Java Year 2011) yang merupakan momen bagi para komponen pariwisata Jawa Timur untuk lebih membangkitkan kepariwisataan diharapkan dapat lebih meningkatkan jumlah kunjungan wisatawan khususnya wisatawan mancanegara.

Pertimbangan mengambil obyek penelitian industri hotel khususnya hotel melati di Jawa Timur karena sebenarnya prospek yang sangat baik, namun perkembangan jumlah kunjungan maupun tingkat hunian kamar berfluktuasi. Berdasarkan data dari Dinas Kebudayaan dan Pariwisata Jawa Timur (2011), Jumlah tamu yang berkunjung di hotel melati, untuk wisatawan manca negara (wisman) dari tahun 2004 ke tahun 2005 mengalami kenaikan yang cukup banyak, yaitu dari 21.203 orang pada tahun 2004 menjadi 93.952 orang di tahun 2005. Akan tetapi sejak tahun 2005 sampai dengan tahun 2009 mengalami penurunan. Pada tahun 2009 wisman yang berkunjung di hotel melati hanya sebanyak 40.606 orang, sedangkan untuk wisatawan nusantara (wisnus) sejak tahun 2005 sampai tahun 2009 terus mengalami penurunan. Pada tahun 2005 sebanyak 2.582.066 orang, sedangkan tahun 2009 sebanyak 1.583.249 orang.

Sekalipun industri hotel melati sebagai usaha kecil (small business), yang mungkin tidak merumuskan secara tertulis misi, visi dan strategi perusahaan tetapi penelitian mengenai orientasi kewirausahaan dan orientasi pasar justru sangat diperlukan untuk pengembangan kinerja pemasarannya. Sesuai dengan yang dikemukakan Pelham dan Wilson (1996), bahwa small business adalah suatu bisnis yang justru mempunyai kemampuan yang kuat untuk melakukan orientasi pasar karena memiliki dua karakteristik yang tidak dimiliki usaha besar, yaitu: (1) memiliki budaya dimana hubungan antar orang dalam organisasi lebih kohesif dan struktur organisasi lebih sederhana, dan (2) jumlah lini produk dan pelanggan yang lebih terbatas.

Keberhasilan dalam usaha diperlukan adanya kemampuan entrepreneur (wirausaha) dalam menjalankan usahanya (Priyanto, 2004). Kewirausahaan juga membutuhkan kemauan untuk menghitung dan mengambil risiko. Teori-teori manajemen pemasaran menyatakan bahwa kinerja pemasaran dapat dipengaruhi melalui pengembangan filosofi manajemen pemasaran yang lebih berorientasi pada pasar untuk mendukung dan mendampingi berbagai strategi bauran pemasaran (marketing mix) yang dijalankan oleh perusahaan.

Organisasi merupakan suatu sistem terbuka, maka kinerjanya juga dipengaruhi oleh faktor-faktor lingkungannya, khususnya lingkungan pemasaran. Perreault dan Mc.Carthy (1999) menyatakan bahwa lingkungan pemasaran terdiri dari lingkungan ekonomi, teknologi, politik, hukum dan sosial budaya.

Berdasarkan temuan penelitian sebelumnya didapatkan celah penelitian, baik dilihat dari variabel penelitian maupun hubungan antar variabel penelitian, yaitu: 
1) Ada kontroversi hasil penelitian dalam hubungan variabel orientasi kewirausahaan, orientasi pasar, lingkungan pemasaran dan kinerja pemasaran.

Dimensi yang digunakan untuk mengukur Orientasi Kewirausahaan dalam penelitian ini berdasar pada Covin dan Slevin (1989), yaitu inovatif, proaktif dan keberanian mengambil resiko, sedangkan dimensi yang digunakan untuk mengukur Orientasi Pasar berdasar pada Narver dan Slater (1990) yaitu Orientasi pada pelanggan, orientasi pada pesaing, koordinasi antar fungsi, fokus jangka panjang dan profitabilitas.

2) Penelitian ini mengkaji gejolak pasar dan budaya sebagai moderasi pengaruh orientasi kewirausahaan, orientasi pasar terhadap kinerja pemasaran, sedangkan penelitian sebelumnya belum ada yang meneliti pengaruh orientasi kewirausahaan terhadap kinerja yang di moderasi gejolak pasar dan budaya.

Penelitian dengan menggunakan moderasi gejolak pasar dan budaya yang merupakan indikator lingkungan pemasaran ini penting dilakukan, karena suatu organisasi merupakan suatu sistem terbuka, maka kinerjanya juga dipengaruhi oleh faktor-faktor lingkungannya, khususnya lingkungan pemasaran. Berdasarkan proposisi Kohli dan Jaworski (1990) kuat lemahnya hubungan antara orientasi pasar dengan kinerja perusahaan juga dipengaruhi oleh keadaan lingkungannya. Demikian pula menurut Hirsch dan Peter (1992), Kewirausahaan adalah suatu proses yang dinamis, yang selalu dipengaruhi faktor-faktor lingkungan. Lingkungan pemasaran sebagai sebuah konsep yang digunakan dalam penelitian ini ada dua variabel yaitu gejolak pasar dan budaya. Kedua variabel ini dapat memperkuat atau memperlemah pengaruh antara orientasi kewirausahaan dan orientasi pasar terhadap kinerja pemasaran.

3) Penelitian sebelumnya belum memasukkan variabel budaya sebagai variabel lingkungan pemasaran yang memoderasi pengaruh orientasi kewirausahaan, orientasi pasar terhadap kinerja. Untuk itu penelitian ini bermaksud mengisi celah penelitian yang ada dengan menggunakan gejolak pasar dan budaya sebagai variabel moderator yang mempengaruhi kuat/lemahnya pengaruh orientasi kewirausahaan dan orientasi pasar terhadap kinerja pemasaran.

4) Ukuran kinerja pemasaran dalam penelitian ini adalah tingkat hunian kamar (room occupancy rate) yang dapat dicapai hotel. Banyak penelitian yang dilakukan di sektor jasa tetapi di hospital/health care dan entertainment dengan indikator yang berbeda dengan obyek penelitian.

Berdasar uraian di atas, maka rumusan masalah penelitian ini adalah:

1) Apakah orientasi kewirausahaan berpengaruh terhadap kinerja pemasaran pada hotel melati di Jawa Timur?

2) Apakah orientasi pasar berpengaruh terhadap kinerja pemasaran pada hotel melati di Jawa Timur?

3) Apakah semakin kuat lingkungan pemasaran (gejolak pasar dan budaya) semakin kuat pengaruh orientasi kewirausahaan terhadap kinerja pemasaran pada hotel melati di Jawa Timur?

Gejolak Pasar Dan Budaya Sebagai Moderasi (Ayun Maduwinarti) 
4) Apakah semakin kuat lingkungan pemasaran (gejolak pasar dan budaya) semakin kuat pengaruh orientasi pasar terhadap kinerja pemasaran pada hotel melati di Jawa Timur?

Secara rinci tujuan penelitian ini adalah:

1) Untuk mengetahui pengaruh orientasi kewirausahaan terhadap kinerja pemasaran pada hotel melati di Jawa Timur.

2) Untuk mengetahui pengaruh orientasi pasar terhadap kinerja pemasaran pada hotel melati di Jawa Timur.

3) Untuk mengetahui pengaruh lingkungan pemasaran (gejolak pasar dan budaya) terhadap kuat lemahnya pengaruh orientasi kewirausahaan terhadap kinerja pemasaran pada hotel melati di Jawa Timur.

4) Untuk mengetahui pengaruh lingkungan pemasaran (gejolak pasar dan budaya) terhadap kuat lemahnya pengaruh orientasi pasar terhadap kinerja pemasaran pada hotel melati di Jawa Timur.

\section{TINJAUAN TEORETIS}

\section{Pengertian Industri Perhotelan}

Pengertian hotel menurut Hotel Proprietors Act (dalam Sulastiyono, 2006) adalah suatu perusahaan yang dikelola oleh pemiliknya dengan menyediakan pelayanan makanan, minuman dan fasilitas kamar untuk tidur kepada orang-orang yang sedang melakukan perjalanan dan mampu membayar dengan jumlah yang wajar sesuai dengan pelayanan yang diterima tanpa adanya perjanjian khusus.

Berdasarkan fasilitas yang disediakan pihak hotel, maka hotel dapat dibagi menjadi: (1) hotel berbintang dan (2) hotel melati. Hotel berbintang selanjutnya dikelompokkan lagi menjadi hotel bintang 1, 2, 3, 4, 5 .

Kelas hotel ditentukan oleh Dinas Pariwisata Daerah (Diparda):

a. Hotel Berbintang, adalah suatu bidang usaha yang menggunakan suatu bangunan atau sebagian bangunan yang disediakan secara khusus, untuk setiap orang yang menginap, makan, memperoleh pelayanan dan menggunakan fasilitas lainnya dengan pembayaran, dan telah memenuhi persyaratan sebagai hotel berbintang seperti yang ditentukan oleh Dinas Pariwisata Daerah (Disparda).

b. Akomodasi Lainnya adalah suatu usaha yang menggunakan suatu bangunan atau sebagian bangunan yang disedikan secara khusus, di mana setiap orang dapat menginap dengan atau tanpa makan dan memperoleh pelayanan serta menggunakan fasilitas lainnya dengan pembayaran. Akomodasi lainnya meliputi: hotel melati, penginapan remaja, pondok wisata dan jasa akomodasi lainnya.

Tingkat Penghunian Kamar Hotel adalah banyaknya malam kamar yang dihuni dibagi dengan banyaknya malam kamar yang tersedia dikalikan 100\%. 


\section{Pengertian Kewirausahaan dan Orientasi Kewirausahaan}

Kewirausahaan adalah seseorang yang memiliki tindakan kreatif yang membangun nilai dari sesuatu yang tidak nampak sebelumnya. Hal tersebut merupakan upaya pengejaran kesempatan tanpa peduli terhadap sumberdaya atau ketiadaan sumberdaya di tangannya. Ini membutuhkan visi, kegemaran dan komitmen untuk memimpin yang lain mencapai visi tersebut. Kewirausahaan adalah suatu proses yang dinamis, yang selalu dipengaruhi faktor lingkungan. Bagi orang ekonom, menjadi seorang wirausaha berarti dapat mengelola material dan asset lain menjadi kombinasi yang meningkatkan nilai tambah lebih tinggi dari sebelumnya, juga mengenalkan pada perubahan, inovasi, dan aturan baru (Hirsch dan Peters, 1992).

Enterpreneurial Orientation (EO) memberikan kontribusi terhadap kinerja, dan didefinisikan sebagai sebuah ukuran majemuk (compound, gabungan dari beberapa komponen) yang mencakup dimensi-dimensi pertumbuhan dan juga mencakup kinerja keuangan (Wiklund, 1999) sehingga keberanian mengambil risiko, inovatif dan sikap proaktif akan membuat perusahaan-perusahaan kecil bisa mengalahkan pesaing-pesaing mereka.

\section{Orientasi Pasar (Market Orientation)}

Orientasi pasar merupakan budaya bisnis yang menjalankan organisasi ke arah penciptaan nilai yang bermutu bagi konsumen secara terus-menerus (Slater dan Narver, 1994). Menurut Varadarajan dan Jayachandran (1999), orientasi pasar adalah seperangkat tindakan nyata yang memungkinkan perusahaan mempertahankan variasi permintaan dan penawaran pasar dan memberikan respon yang tepat terhadap berbagai perubahan yang terjadi. Konsep pemasaran mengenal bahwa tidak adanya alasan mengapa konsumen membeli suatu produk yang ditawarkan oleh suatu organisasi, sekalipun ada produk pesaing, dan konsumen akan memilih produk dan jasa yang paling memuaskan kebutuhan dan keinginan mereka. Perusahaan yang mengadopsi dan mengimplementasikan konsep pemasaran setuju dengan orientasi pasar. Penelitian yang dilakukan Narver dan Slater (1990) menyimpulkan bahwa orientasi pasar terdiri atas tiga komponen penting yaitu : a) orientasi kepada pelanggan, b) orientasi kepada pesaing, c) koordinasi antar fungsi dan dua kriteria keputusan yaitu: d) fokus jangka panjang dan f) profitabilitas

\section{Lingkungan Pemasaran}

Perusahaan sebagai sistem terbuka tidak pernah dapat dipisahkan dengan lingkungannya. Karena fungsi pemasaran merupakan salah satu fungsi dari keseluruhan fungsi yang ada dalam perusahaan, maka efektivitasnya juga dipengaruhi oleh lingkungannya. Lingkungan pemasaran terdiri dari pemeran-pemeran dan kekuatan-kekuatan di luar pemasaran yang dipengaruhi kemampuan manajemen pemasaran untuk mengembangkan dan mempertahankan transaksi yang berhasil dengan pasar sasaran (Amstrong dan Kotler, 2000).

Gejolak Pasar Dan Budaya Sebagai Moderasi (Ayun Maduwinarti) 
Lingkungan budaya yang menjadi fokus dalam penelitian ini, mencakup lembaga dan kekuatan lain yang mempengaruhi nilai-nilai, persepsi, dan tingkah laku dasar masyarakat. Sebagai wujud yang kolektif, masyarakat membentuk keyakinan dan nilainilai dasar anggotanya. Karakter budaya yang dapat mempengaruhi pengambilan keputusan pemasaran adalah keteguhan nilai-nilai budaya dan subbudaya. Hasil tinjauan berbagai penelitian sebelumnya dan dukungan teori, maka pada penelitian ini sebagai variabel lingkungan pemasaran adalah gejolak pasar dan budaya.

\section{Kinerja Pemasaran}

Kinerja sebuah perusahaan dapat dilihat dari prestasi berbagai fungsi yang dilaksanakan, termasuk dalam melihat kinerja pemasaran dari pelaksanaan fungsi pemasaran. Kinerja pemasaran sangat tergantung pada keberhasilan perusahaan untuk melaksanakan strategi pemasaran yang tepat. Pengukuran kinerja pemasaran yang merupakan bagian dari kinerja kualitas akan sangat bermanfaat sebagai langkah positif dalam memacu kinerja bisnis itu sendiri. Pengukuran kinerja pemasaran dapat dilakukan pada tiga tingkat, yaitu pada tingkat proses (process level), tingkat output (output level), tingkat outcome (outcome level). Pengukuran kinerja pemasaran dalam penelitian ini adalah room occupancy rate (tingkat hunian kamar).

\section{Penelitian Terdahulu}

\section{Hasil Penelitian Sebelumnya Orientasi Kewirausahaan dan Kinerja Pemasaran}

Beberapa hasil penelitian sebelumnya menyatakan bahwa Orientasi Kewirausahaan mempunyai pengaruh yang positif terhadap kinerja yaitu hasil penelitian Miler dan Friesen (1982); Miler (1983); Covin dan Slevin, 1989; Covin dan Slevin, 1991); Baker dan Sinkula (1999); Tzokas et al. (2001); Bhuian et al., (2002); Jogaratman, Ching dan Tse (2006); Zyl dan Helm (2007) dan Yua Li, et al., (2008), sedangkan beberapa hasil penelitian terdahulu yang memberikan hasil orientasi kewirausahaan mempunyai pengaruh negatif terhadap kinerja adalah Naldi et al., (2007); Frishammar dan Horte (2007) serta Baker dan Sinkula (2009).

\section{Hasil Penelitian Sebelumnya Orientasi Pasar dan Kinerja Pemasaran}

Hasil penelitian sebelumnya yang menyatakan bahwa Orientasi Pasar mempunyai pengaruh yang positif terhadap kinerja yaitu Naver dan Slater (1990); Raju, Lonial dan Gupta et al., (1995); Pelham (2000); Tzokas et al., (2001); Vitale et al., 2001; Gima dan Anthony, 2001; Bhuian (2002); Matsuno dan Mentzer (2000); Frishammar dan Horte (2007); Yua Li et al., (2008); Baker dan Sinkula (2009), sedangkan beberapa hasil penelitian terdahulu yang memberikan hasil orientasi pasar mempunyai pengaruh negatif terhadap kinerja adalah Jaworski dan Kohli (1993); Greenley (1995) dan Renko et al. (2009) 
Hasil Penelitian Sebelumnya Gejolak Pasar dan Budaya sebagai moderasi Terhadap Kuat Lemahnya Pengaruh Orientasi Kewirausahaan, Orientasi Pasar Terhadap Kinerja

Beberapa hasil penelitian sebelumnya yang menggunakan moderasi lingkungan pemasaran untuk melihat kuatnya pengaruh Orientasi Kewirausahaan, orientasi pasar terhadap kinerja yaitu Dilts dan Prough (2001); Augusto dan Coelho (2006); Ngamkroeckjoti dan Speece (2008); dan Subramanian et al., (2009), sedangkan beberapa hasil penelitian sebelumnya yang menggunakan moderasi lingkungan pemasaran untuk melihat lemahnya pengaruh Orientasi Kewirausahaan, orientasi pasar terhadap kinerja yaitu Slater dan Narver (1994); Pelham (1997); Subramanian et al., (2009).

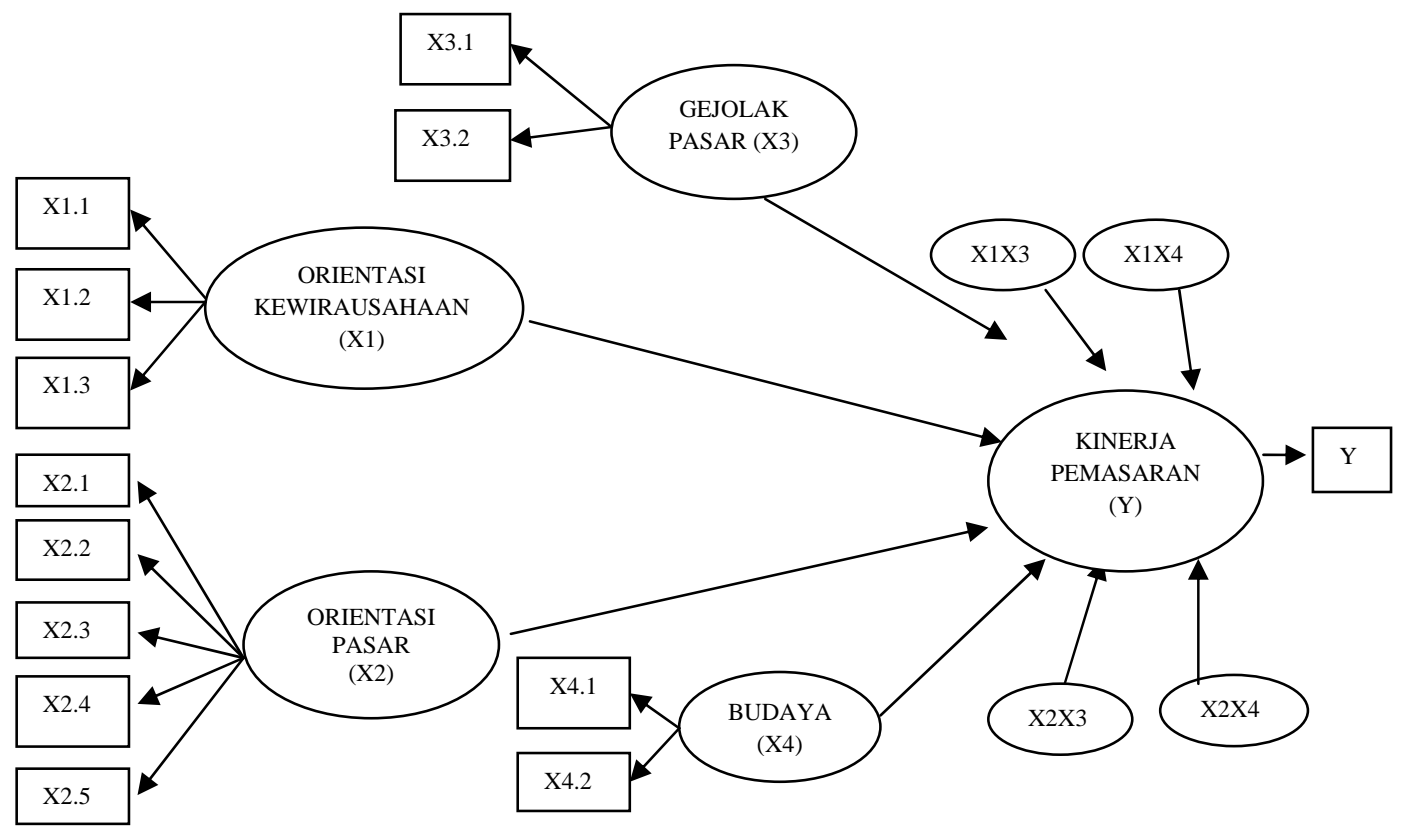

Gambar 1

Rerangka Konseptual

Keterangan:

$\mathrm{X}_{1.1}$ : Inovatif

$\mathrm{X}_{1.2}$ : Proaktif

$\mathrm{X}_{1.3}$ : Keberanian Mengambil Resiko

$\mathrm{X}_{2.1}$ : Orientasi Pada Pelanggan

$\mathrm{X}_{2.2}$ : Orientasi Pada Pesaing

$\mathrm{X}_{2.3}$ : Koordinasi Antar Fungsi

$\mathrm{X}_{2.4}$ : Fokus Jangka Panjang

$\mathrm{X}_{2.5}$ : Profitabilitas

Gejolak Pasar Dan Budaya Sebagai Moderasi (Ayun Maduwinarti) 
$\mathrm{X}_{3.1}$ : Komposisi Konsumen

$\mathrm{X}_{3.2}$ : Preferensi Konsumen

$\mathrm{X}_{4.1}$ : Keteguhan Nilai-nilai Budaya

$\mathrm{X}_{4.2}$ : Subbudaya

$\mathrm{X}_{1.3}$ : Interaksi Orientasi Kewirausahaan dengan Gejolak Pasar

$\mathrm{X}_{1.4}$ : Interaksi Orientasi Kewirausahaan dengan Budaya

$\mathrm{X}_{2.3}$ : Interaksi Orientasi Pasar dengan Gejolak Pasar

$\mathrm{X}_{2.4}$ : Interaksi Orientasi Pasar dengan Budaya

Berdasarkan rumusan-rumusan masalah yang telah dikemukakan dan rerangka konseptual yang dibangun, maka dapat dibangun rumusan hipotesa seperti berikut:

H1 : Orientasi Kewirausahaan berpengaruh terhadap kinerja pemasaran

$\mathrm{H} 2$ : Orientasi pasar berpengaruh terhadap kinerja pemasaran

H3a: Semakin pasar bergejolak semakin kuat pengaruh orientasi kewirausahaan terhadap kinerja pemasaran.

H3b: Semakin kuat budaya semakin kuat pengaruh orientasi kewirausahaan terhadap kinerja pemasaran.

H4a: Semakin pasar bergejolak semakin kuat pengaruh orientasi pasar terhadap kinerja pemasaran.

H4b: Semakin kuat budaya semakin kuat pengaruh orientasi pasar terhadap kinerja pemasaran.

\section{METODE PENELITIAN}

\section{Pendekatan Penelitian}

Pendekatan penelitian yang digunakan adalah positivist paradigm karena menggunakan aturan-aturan baku. Penelitian ini adalah penelitian kuantitatif karena, (1) bertujuan mengkuantitatifkan data dan membuat generalisasi hasil sampel dari populasi, (2) jumlah sampelnya banyak, (3) dilakukan secara terstruktur, (4) analisis data menggunakan statistik, dan (5) hasil penelitian untuk memberi rekomendasi (Maholtra, 2004) dan cross-sectional, karena dalam rentang waktu yang bersamaan dilakukan pencatatan atas persepsi dari para pimpinan atau manajer hotel, sedangkan sifat hubungan antar variabelnya termasuk dalam penelitian kausalitas karena penelitian ini direncanakan untuk mengetahui hubungan antar variabel dengan hasil yang dapat dipergunakan sebagai masukan bagi pengambil keputusan.

\section{Tempat dan Waktu Penelitian}

Penelitian ini dilakukan di Jawa Timur. Alasan pemilihan tempat penelitian di JawaTimur karena: (1) Jawa Timur sebagai provinsi kedua di Indonesia yang begitu cepat perkembangannya berkaitan dengan lingkungan khususnya yang berkaitan dengan lingkungan pemasaran, yaitu gejolak pasar, budaya, sehingga sangat mempengaruhi latar 
belakang masyarakat untuk memutuskan menginap di hotel dan memaksa industri hotel melati merespon perubahan-perubahan tersebut, (2) peneliti dan tenaga peneliti mengenal daerah Jawa Timur, sehingga memudahkan dalam mengakses informasi dan mengenali lebih mendalam fenomena industri hotel melati di Jawa Timur.

Penelitian dilakukan selama 5 Bulan. Penyusunan instrumen, penyebaran kuesioner, pengujian validitas dan reliabilitas instrumen, dan pengumpulan data dilakukan pada bulan Juli sampai dengan Agustus 2010, sedangkan untuk pengolahan dan analisis data, pembahasan serta penyusunan laporan dilakukan bulan Januari sampai dengan Maret 2011.

\section{Populasi dan Sampel}

Populasi dalam penelitian ini adalah seluruh hotel melati di Jawa Timur. Jumlah populasi hotel melati sebanyak 463 hotel yang tersebar di kota dan kabupaten di Jawa Timur

Unit sampelnya adalah hotel melati di beberapa kota/kabupaten di Jawa Timur, sedangkan respondennya adalah para pemilik hotel melati atau manajer puncak. Jumlah sampel sebanyak 90 responden. Penetapan sampel dilakukan dengan 2 tahap, tahap 1: untuk menetapkan sampel wilayah digunakan Judgment Sampling, dimana sampel dipilih dengan menggunakan pertimbangan tertentu yang disesuaikan dengan tujuan penelitian atau masalah penelitian yang dikembangkan. Misalnya karena peneliti menyadari bahwa yang memiliki informasi "baik dan benar" mengenai perusahaan adalah seorang manajer, maka ia menentukan sampelnya adalah para manajer (Ferdinand, 2006), sedangkan tahap 2: untuk menetapkan jumlah sampel hotel melati pada masing-masing kota/kabupaten yang sudah terpilih dengan cara Proportional Area Random Sampling, artinya bahwa pengambilan sampel dilakukan secara acak (random) pada setiap wilayah yang terdapat dalam populasi dan besarnya sampel setiap wilayah proporsional atau sebanding dengan besarnya subyek wilayah yang bersangkutan.

\section{Metode Pengumpulan Data}

\section{Sumber Data}

Data primer dalam penelitian ini diperoleh dengan cara memberikan kuesioner kepada para pemilik/manajer hotel yang dipakai sebagai sampel, sedangkan data sekunder diperoleh dari lembaga yang menerbitkan data yang terkait dengan permasalahan penelitian dan digunakan untuk menyempurnakan data yang diperoleh dari sumber primer serta dari berbagai laporan dan publikasi yang relevan dengan masalah kepariwisataan dan perhotelan. 


\section{Teknik Pengumpulan Data}

Pengumpulan data dilakukan dengan menyebarkan kuesioner, sedangkan pengumpulan data dari wawancara digunakan untuk memperjelas dari jawaban-jawaban kuesioner dan temuan-temuan yang secara implisit menjadi kebijakan dan kondisi perusahaan. Untuk menjawab item-item pertanyaan yang berkaitan dengan derajat atau kecenderungan beberapa subvariabel dalam penelitian ini digunakan Skala Likert.

\section{Variabel dan Definisi Operasional Variabel adalah:}

1. Orientasi Kewirausahaan $\left(\mathrm{X}_{1}\right)$ adalah berkaitan dengan aspek psikometrik yang dilihat dari inovasinya, sifat proaktifnya dan keberanian mengambil resiko, dengan indikator: Inovatif $\left(\mathrm{X}_{1.1}\right)$, Proaktif $\left(\mathrm{X}_{1.2}\right)$ dan Keberanian Mengambil Resiko $\left(\mathrm{X}_{1.3}\right)$

2. Orientasi pasar $\left(\mathrm{X}_{2}\right)$ merupakan budaya bisnis yang menjalankan organisasi ke arah penciptaan nilai yang bermutu bagi konsumen secara terus-menerus, dengan indikator: Orientasi pada pelanggan $\left(\mathrm{X}_{2.1}\right)$, orientasi pada pesaing $\left(\mathrm{X}_{2.2}\right)$, koordinasi antar fungsi $\left(\mathrm{X}_{2.3}\right)$, Fokus jangka panjang $\left(\mathrm{X}_{2.4}\right)$, dan Profitabilitas $\left(\mathrm{X}_{2.5}\right)$.

3. Gejolak pasar $\left(\mathrm{X}_{3}\right)$ adalah tingkat perubahan komposisi pelanggan dan preferensinya, dengan indikator: Komposisi Konsumen $\left(\mathrm{X}_{3.1}\right)$ dan Preferensi Konsumen $\left(\mathrm{X}_{3.2}\right)$.

4. Budaya $\left(\mathrm{X}_{4}\right)$ merupakan suatu pengetahuan dimana orang akan mempergunakannya untuk mengartikan pengalamannya yang akan menghasilkan suatu sikap dan perilaku sosial, dengan indikator: Keteguhan Nilai-nilai Budaya $\left(\mathrm{X}_{4.1}\right)$ dan Subbudaya $\left(\mathrm{X}_{4.2}\right)$.

5. Kinerja pemasaran (Y), merupakan prestasi yang dicapai oleh organisasi yang dilihat dari hasil pemasarannya, dengan indikator: Room Occupancy Rate/Tingkat Hunian Kamar $\left(\mathrm{Y}_{1}\right)$.

\section{Teknik Analisis Data}

Teknik analisis yang digunakan adalah dengan analisis deskriptif dan analisis inferensial dengan menggunakan Partial Least Square (PLS).

\section{ANALISIS DAN PEMBAHASAN}

\section{Hasil Pengujian Asumsi Linieritas}

Metode uji asumsi linieritas yang digunakan adalah Curve Fit, di mana perhitungannya dilakukan dengan bantuan software SPSS. Rujukan yang digunakan adalah prinsip parsimony, yaitu bilamana seluruh model yang digunakan sebagai dasar pengujian signifikan atau nonsignifikan berarti model dikatakan linier. Dari hasil analisa dengan PLS menunjukkan bahwa semua hubungan dalam model adalah linear.

\section{Pemodelan Persamaan Struktural Pendekatan Partial Least Square (PLS)}

Selanjutnya dalam upaya memperoleh model yang power full, setelah menetapkan inner model (model structural) dan outer model (model pengukuran) yang telah dilakukan pada 
bab metodologi maka dilakukan evaluasi model empiric penelitian. Secara visual hasil pengujian atau evaluasi PLS model empiris penelitian dapat dilihat pada Gambar 2.

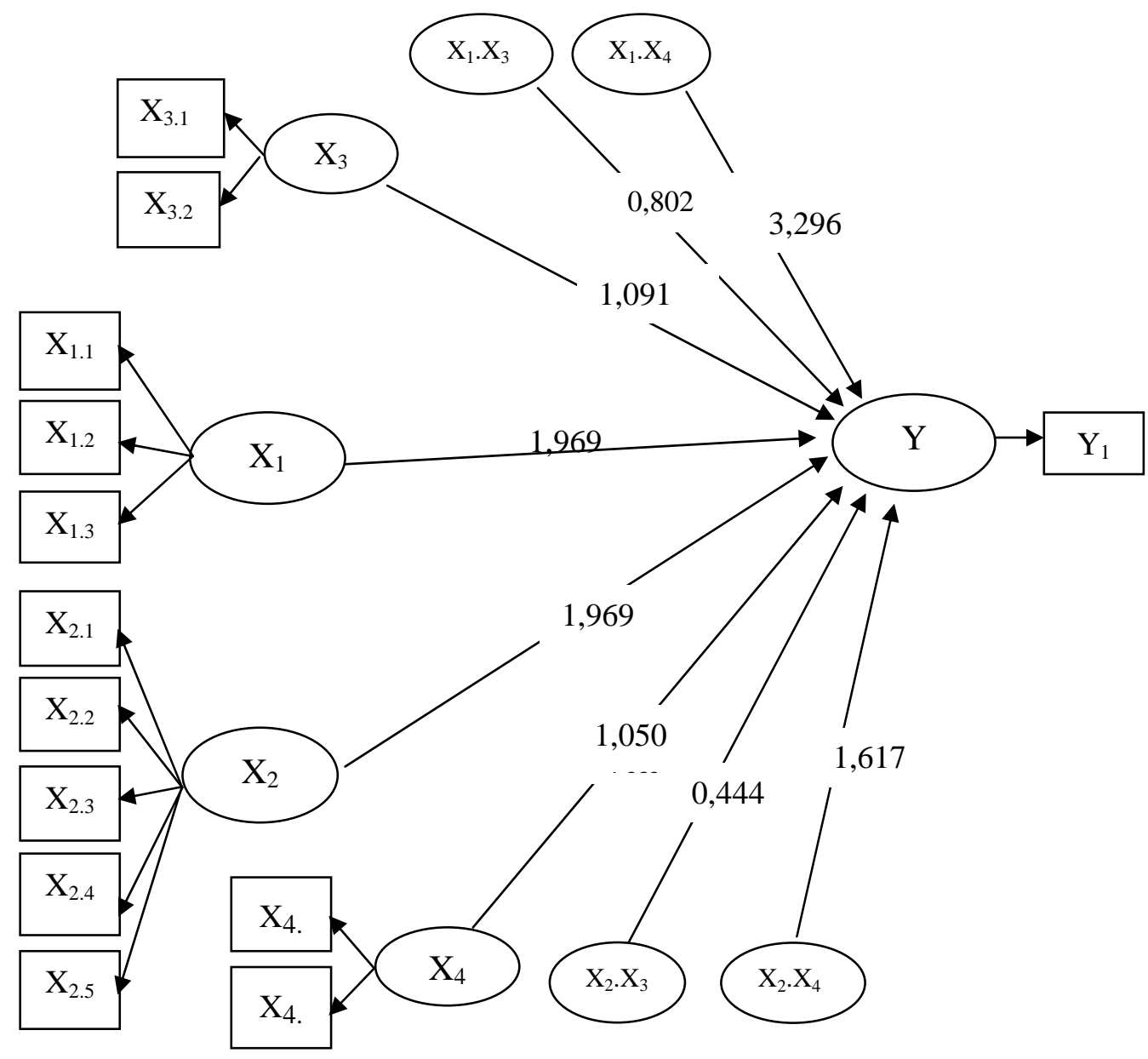

Gambar 2

Model Empirik Penelitian

\section{Hasil PemeriksaanGoodness of Fit Model}

Pemeriksaan goodness of fit model dalam analisis PLS dapat dilihat dari nilai predictiverelevance $\left(\mathrm{Q}^{2}\right)$, dihitung berdasarkan nilai $\mathrm{R}^{2}$ masing-masing variabel endogen. Mengingat model structural di dalam penelitian ini variabel endogennya hanya satu, maka nilai predictive-relevance $\left(\mathrm{Q}^{2}\right)$ sama dengan nilai $\mathrm{R}^{2}$. Berdasarkan hasil analisis diperoleh nilai $\mathrm{R}^{2}=0,685$. Dengan demikian diperoleh nilai $\mathrm{Q}^{2}=68,5 \%$, sehingga model dikatakan baik dan layak digunakan untuk pegujian hipotesis. 


\section{Factors Loading dan Rerata Skor setiap Indikator}

Identifikasi indikator penting (dominan) didasarkan pada nilai factor loading. Indikator dengan factor loading terbesar adalah sebagai pengukur variabel laten yang terkuat (dominan).

Tabel 1

Outer Loading Setiap Indikator Dari Masing-Masing Variabel

\begin{tabular}{ccccc}
\hline Variabel & Indikator & $\begin{array}{c}\text { Factors } \\
\text { Loading }\end{array}$ & $\begin{array}{c}\text { Rerata } \\
\text { Indikator }\end{array}$ & $\begin{array}{c}\text { Rerata } \\
\text { Variabel }\end{array}$ \\
\hline \multirow{2}{*}{$\mathrm{X}_{1}$} & $\mathrm{X}_{1.1}$ & $\mathbf{0 . 9 0 2}$ & 3.89 & \\
& $\mathrm{X}_{1.2}$ & 0.848 & 3.91 & 3.91 \\
& $\mathrm{X}_{1.3}$ & 0.861 & 3.94 & \\
\hline \multirow{2}{*}{$\mathrm{X}_{2}$} & $\mathrm{X}_{2.1}$ & 0.753 & 3.86 & \\
& $\mathrm{X}_{2.2}$ & 0.820 & 3.78 & \\
& $\mathrm{X}_{2.3}$ & 0.798 & 3.81 & 3.80 \\
& $\mathrm{X}_{2.4}$ & 0.804 & 3.71 & \\
& $\mathrm{X}_{2.5}$ & 0.863 & 3.87 & \\
\hline \multirow{2}{*}{$\mathrm{X}_{3}$} & $\mathrm{X}_{3.1}$ & 0.880 & 3.56 & \multirow{2}{*}{3.41} \\
\hline \multirow{2}{*}{$\mathrm{X}_{4}$} & $\mathrm{X}_{3.2}$ & 0.888 & 3.27 & \\
& $\mathrm{X}_{3.3}$ & 0.894 & 3.74 & \multirow{2}{*}{3,92} \\
\hline
\end{tabular}

Sumber : Hasil Analisa PLS

Tabel 1, menunjukkan bahwa indikator Inovatif $\left(\mathrm{X}_{1 \cdot 1}\right)$ adalah indikator terkuat sebagai pengukur variabel Orientasi Kewirausahaan $\left(\mathrm{X}_{1}\right)$. Rerata dari indikator tersebut adalah 3,89 dapat dikatakan cukup. Dengan demikian dapat diketahui bahwa inovasi $\left(\mathrm{X}_{1 \cdot 1}\right)$ hotel melati adalah penting, namun para pengelola hotel belum melakukannya dengan baik, sedangkan Indikator Profitabilitas $\left(\mathrm{X}_{2 \cdot 5}\right)$ adalah merupakan indikator terkuat sebagai pengukur variabel Orientasi Pasar $\left(\mathrm{X}_{2}\right)$. Rerata dari indikator tersebut adalah 3,87 dapat dikatakan cukup. Dengan demikian dapat diketahui bahwa Profitabilitas $\left(\mathrm{X}_{2 \cdot 5}\right)$ hotel melati adalah penting, namun para pengelola hotel belum melakukannya dengan baik.

Untuk indikator Preferensi Konsumen $\left(\mathrm{X}_{3 \cdot 2}\right)$ adalah indikator terkuat sebagai pengukur variabel Gejolak Pasar $\left(\mathrm{X}_{3}\right)$. Rerata dari indikator tersebut adalah 3,27 dapat dikatakan cukup. Dengan demikian dapat diketahui bahwa Preferensi Konsumen $\left(\mathrm{X}_{3 \cdot 2}\right)$ hotel melati adalah penting, namun para pengelola hotel belum melakukannya dengan baik. Indikator Keteguhan nilai-nilai budaya $\left(\mathrm{X}_{4 \cdot 1}\right)$ adalah indikator terkuat sebagai pengukur variabel Budaya $\left(\mathrm{X}_{4}\right)$. Rerata dari indikator tersebut adalah 3,74 dapat dikatakan cukup. Hal ini 
berarti bahwa keteguhan nilai-nilai budaya $\left(\mathrm{X}_{4 \cdot 1}\right)$ hotel melati adalah penting, akan tetapi para pengelola hotel melati belum melakukannya dengan baik.

\section{Hasil Pengujian Hipotesis}

Analisis jalur digunakan untuk pengujian hipotesis pada penelitian ini. Pendekatan yang digunakan dalam proses perhitungan adalah dengan Standardize Regression.

Hasil pengujian hipotesis jalur-jalur pengaruh langsung dapat dilihat pada diagram jalur berikut.

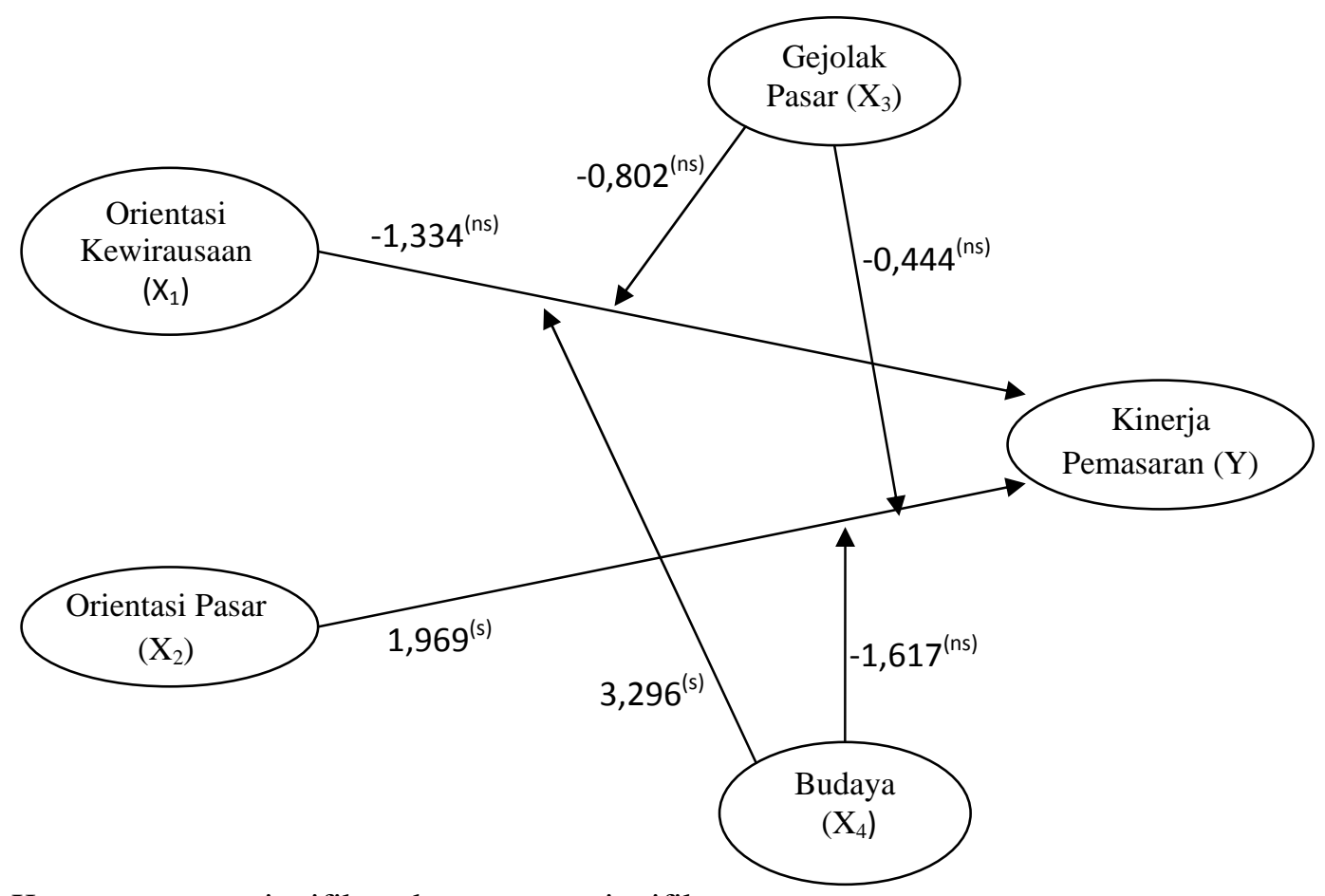

Keterangan: $\mathrm{s}=$ signifikan dan ns $=$ nonsignifikan

\section{Gambar 3}

\section{Diagram Jalur Pengaruh Langsung}

Berdasarkan Gambar 3 didapatkan hasil pengujian hipotesis sebagai berikut:

\section{Pengaruh Orientasi Kewirausahaan terhadap Kinerja Pemasaran}

Berdasarkan hasil analisis PLS, diperoleh koefisien jalur sebesar -1,334 dengan $\mathrm{p}=0,063$, sehingga dikatakan tidak signifikan. Artinya bahwa Orientasi Kewirausahaan $\left(\mathrm{X}_{1}\right)$ berpengaruh tidak signifikan terhadap Kinerja Pemasaran (Y).

Gejolak Pasar Dan Budaya Sebagai Moderasi (Ayun Maduwinarti) 
Kondisi empiris hotel melati di Jawa Timur, orientasi kewirausahaan justru memiliki hubungan yang negatif terhadap kinerja pemasaran dalam hal ini tingkat hunian kamar, artinya semakin tinggi pemilik/manajer menerapkan orientasi kewirausahaan maka tingkat hunian kamar semakin menurun. Hal ini terbukti dari nilai koefisien jalur bertanda negatif. Pengaruh negatif orientasi kewirausahaan terhadap kinerja pemasaran pada hotel melati terkait dengan karakteristik hotel melati dimana apabila pengelola semakin berinovasi maka tamu akan pindah pada hotel melati yang lain bahkan ke hotel bintang 1 . Ketika mereka melakukan inovasi baik berkaitan dengan fasilitas, pelayanan dan menu hotel misalnya maka mereka akan mengeluarkan biaya yang akhirnya dibebankan kepada tamu hotel melalui harga kamar.

Disamping itu pemilik/manajer hotel melati belum mampu memasuki segmen-segmen potensial dan tidak memiliki terobosan untuk mendahului pesaing-pesaingnya karena ketidakmampuan pemilik/manajer hotel melati dalam mengaplikasikan nilai proaktif. Demikian pula tidak adanya keberanian untuk menanggung resiko dalam menciptakan kinerja pemasaran yang optimal dalam hal ini mengoptimalkan tingkat hunian kamar. Untuk bisa mewujudkan hal ini maka pemilik/manajer hotel melati harus memahami dengan detail kebutuhan pasar agar nilai inovatif, proaktif dan keberanian mengambil resiko benar-benar tepat sasaran. Dengan demikian dapat disimpulkan bahwa hipotesis satu $\left(\mathrm{H}_{1}\right)$ yang menyatakan bahwa orientasi kewirausahaan berpengaruh terhadap kinerja pemasaran ditolak atau tidak didukung dengan fakta.

Hasil penelitian ini tidak sesuai dengan hasil penelitian Gima (2001), Wiklund (1999), Vitale et al., (2002), Bhuian (2002), Zyl (2007) dan Yuan (2008). Hasil penelitian terdahulu diperoleh hasil adanya pengaruh yang positif antara orientasi kewirausahaan terhadap kinerja. Namun hasil penelitian ini mendukung hasil penelitian Naldi et al. (2007) yang meneliti orientasi kewirausahaan pada perusahaan keluarga. Dari hasil penelitiannya diketahui bahwa orientasi kewirausahaan dalam perusahaan keluarga khususnya untuk risk taking, mempunyai hubungan yang negatif terhadap kinerja. Sementara itu hasil penelitian Frishammar dan Horte (2007) yang meneliti pada perusahaan manufaktur, menunjukkan proaktif dan risk taking sebagai indikator orientasi kewirausahaan tidak menunjukkan adanya hubungan dengan kinerja. Demikian pula Baker dan Sinkula (2009) yang meneliti pada usaha kecil menemukan bahwa orientasi kewirausahaan tidak berpengaruh terhadap profit.

\section{Pengaruh Orientasi Pasar terhadap Kinerja pemasaran}

Berdasarkan hasil analisis PLS, diperoleh koefisien jalur sebesar 1,969 dengan $\mathrm{p}=0,001$, sehingga dikatakan signifikan. Dengan demikian dapat dikatakan bahwa Orientasi Pasar $\left(\mathrm{X}_{2}\right)$ berpengaruh signifikan terhadap Kinerja Pemasaran (Y). Mengingat koefisien jalur bertanda positif, dapat diartikan bahwa semakin baik orientasi pasar yang dilakukan oleh pengelola hotel melati, maka kinerja pemasaran semakin meningkat. 
Dari temuan ini dapat disimpulkan bahwa hotel-hotel yang lebih berorientasi pasar akan memiliki kinerja yang lebih baik dibanding dengan hotel-hotel yang kurang berorientasi pasar, sehingga orientasi pasar menjadi sesuatu yang penting bagi peningkatan kinerja hotel. Hal ini berarti bahwa semakin manajemen memperhatikan pelanggan dan pesaing, melakukan koordinasi antar fungsi, berfokus pada kepentingan jangka panjang dan laba menjadi sasaran utama, maka semakin tinggi kinerja pemasaran hotel melati.

Dengan memperhatikan bukti-bukti empirik tersebut, maka hipotesis dua $\left(\mathrm{H}_{2}\right)$ yaitu orientasi pasar berpengaruh terhadap kinerja pemasaran terbukti.

Temuan bahwa orientasi pasar berpengaruh terhadap kinerja ini menguatkan temuantemuan sebelumnya bahwa orientasi pasar berpengaruh terhadap kinerja pada usaha kecil, seperti hasil temuan Pelham dan Wilson (1996), Pelham (1997). Temuan ini juga menguatkan temuan-temuan sebelumnya bahwa orientasi pasar juga berpengaruh terhadap kinerja pada industri jasa, seperti hasil temuan Raju et al., (1995). Mengingat bahwa industri hotel melati termasuk industri kecil dan jasa, maka temuan ini konsisten dengan temuan-temuan sebelumnya baik di industri kecil maupun industri jasa.

\section{Gejolak Pasar memoderasi pengaruh orientasi kewirausahaan terhadap kinerja pemasaran}

Berdasarkan hasil analisis PLS, Gejolak Pasar $\left(\mathrm{X}_{3}\right)$ tidak memiliki efek moderasi pengaruh Orientasi Kewirausahaan $\left(\mathrm{X}_{1}\right)$ terhadap Kinerja Pemasaran $(\mathrm{Y})$. Nilai koefisien jalur sebesar $-0,802$ dengan $\mathrm{p}=0$ 0,393 sehingga dikatakan nonsignifikan.

Temuan ini mengindikasikan bahwa sensitifitas tamu terhadap perubahan harga, daya beli tamu dan juga saat-saat ramai atau tidaknya tamu yang menginap di hotel melati tidak mempengaruhi kuat lemahnya pengaruh orientasi pasar terhadap tingkat hunian kamar. Pemilik/manajer hotel bisa saja melakukan inovasi, menerapkan kebijakan proaktif maupun berani dalam menanggung resiko kegagalan dalam mengelola hotel melati tanpa terpengaruh pada gejolak pasar. Temuan penelitian ini sejalan dengan Kohli dan Jaworsky, 1990; Slater dan Naver, 1994, dimana dinyatakan bahwa apabila suatu perusahaan melayani sekelompok konsumen tertentu dengan preferensi yang stabil, orientasi pasar mungkin hanya berpengaruh kecil terhadap kinerja, karena hanya sedikit penyesuaian marketing mix diperlukan untuk memenuhi secara efektif terhadap sekelompok konsumen. Sebaliknya jika sekelompok konsumen preferensinya stabil, kemungkinan penawaran perusahaan menjadi tidak cocok dengan kebutuhan konsumen selama jangka waktu tertentu. Karenanya perusahaan harus mengetahui dengan pasti perubahan preferensi pelanggan dan menyesuaikan penawaran untuk memenuhinya.

Dengan demikian dapat disimpulkan bahwa hipotesis tiga a (H3a) yang menyatakan semakin pasar bergejolak semakin kuat pengaruh orientasi kewirausahaan terhadap kinerja pemasaran ditolak atau tidak didukung dengan fakta.

Gejolak Pasar Dan Budaya Sebagai Moderasi (Ayun Maduwinarti) 


\section{Budaya memoderasi pengaruh orientasi kewirausahaan terhadap kinerja pemasaran}

Pengaruh Budaya $\left(\mathrm{X}_{4}\right)$ dan Interaksi $\left(\mathrm{X}_{1}\right.$. $\left.\mathrm{X}_{4}\right)$ signifikan, sehingga budaya adalah moderasi semu Pengaruh Orientasi Kewirausahaan $\left(\mathrm{X}_{1}\right)$ terhadap Kinerja Pemasaran (Y). Berdasarkan hasil analisis PLS, diperoleh koefisien jalur sebesar 3,296 dengan $p=0,001$, sehingga dikatakan signifikan. Dengan demikian dapat disimpulkan bahwa Budaya $\left(\mathrm{X}_{4}\right)$ adalah moderasi semu Pengaruh Orientasi Kewirausahaan $\left(\mathrm{X}_{1}\right)$ terhadap Kinerja Pemasaran (Y). Koefisien interaksi positif, sehingga sifatnya memperkuat. Hipotesis 3b Semakin kuat budaya semakin kuat pengaruh orientasi kewirausahaan terhadap kinerja pemasaran terbukti. Temuan yang menarik dari penelitian ini adalah orientasi kewirausahaan secara langsung tidak mempunyai pengaruh yang signifikan terhadap kinerja pemasaran dalam hal ini tingkat hunian kamar, akan tetapi setelah di moderasi oleh budaya justru memperkuat pengaruh orientasi kewirausahaan terhadap kinerja pemasaran. Artinya pemilik/manajer hotel melati dalam melaksanakan orientasi kewirausahaan dengan melakukan inovasi, proaktif maupun berani dalam mengambil resiko harus memperhatikan budaya masyarakat.

Dengan demikian dapat disimpulkan bahwa hipotesis tiga b (H3b) yang menyatakan semakin kuat budaya semakin kuat pengaruh orientasi kewirausahaan terhadap kinerja pemasaran terbukti dan didukung oleh fakta.

5. Gejolak Pasar memoderasi pengaruh orientasi pasar terhadap kinerja pemasaran Pengaruh Gejolak Pasar $\left(\mathrm{X}_{3}\right)$ dan Interaksi orientasi pasar dan gejolak pasar $\left(\mathrm{X}_{2} \mathrm{X}_{3}\right)$ tidak signifikan, sehingga Gejolak Pasar $\left(\mathrm{X}_{3}\right)$ tidak memiliki efek moderasi Pengaruh Orientasi Pasar $\left(\mathrm{X}_{2}\right)$ terhadap Kinerja Pemasaran $(\mathrm{Y})$. Berdasarkan hasil analisis PLS, diperoleh koefisien jalur sebesar $-0,444$ dengan $\mathrm{p}=0,483$, sehingga dikatakan nonsignifikan. Dengan demikian dapat disimpulkan bahwa Gejolak Pasar $\left(\mathrm{X}_{3}\right)$ tidak memiliki efek moderasi pengaruh Orientasi Pasar $\left(\mathrm{X}_{2}\right)$ terhadap Kinerja Pemasaran (Y). Temuan penelitian ini tidak mendukung proposisi Kohli dan Jaworski (1990) dan juga temuan Slater dan Naver (1994), dimana dihasilkan semakin kuat gejolak pasar maka semakin perlu kebutuhan orientasi pasar dan semakin kuat pengaruh orientasi pasar terhadap kinerja.

Berdasar pada hasil penelitan di hotel melati, tingkat perubahan komposisi pelanggan atau preferensinya yang ditunjukkan dengan sensitifitas tamu terhadap perubahan harga, daya beli tamu dan juga saat-saat ramai atau tidaknya tamu yang menginap di hotel melati tidak mempengaruhi pengaruh orientasi pasar terhadap tingkat hunian kamar. Kondisi tamu di hotel melati sering tidak terpengaruh oleh harga kamar maupun masa-masa tertentu, misalnya liburan. Dengan demikian dapat disimpulkan bahwa hipotesis empat a (H4a) yang menyatakan semakin pasar bergejolak semakin kuat pengaruh orientasi pasar terhadap kinerja pemasaran ditolak atau tidak didukung dengan fakta. 


\section{Budaya memoderasi pengaruh orientasi pasar terhadap kinerja pemasaran}

Pengaruh Budaya $\left(\mathrm{X}_{4}\right)$ dan Interaksi budaya dan orientasi pasar $\left(\mathrm{X}_{2} \mathrm{X}_{4}\right)$ adalah nonsignifikan, sehingga budaya tidak memiliki efek moderasi pengaruh Orientasi Pasar $\left(\mathrm{X}_{2}\right)$ terhadap Kinerja Pemasaran (Y). Berdasarkan hasil analisis PLS, diperoleh koefisien jalur sebesar $-1,617$ dengan $\mathrm{p}=0,099$, sehingga dikatakan nonsignifikan. Dengan demikian dapat disimpulkan bahwa Budaya $\left(\mathrm{X}_{4}\right)$ adalah tidak memiliki efek moderasi pengaruh Orientasi pasar terhadap Kinerja Pemasaran. Tampaknya pada hotel melati budaya tidak berperan sebagai variabel yang memperkuat pengaruh orientasi pasar terhadap kinerja. Pemilik/manajer hotel melati bisa saja melakukan orientasi terhadap pelanggan, orientasi pada pesaing, koordinasi antar fungsi, berfokus jangka panjang maupun berorientasi pada profit tanpa harus mempertimbangkan norma yang ada pada masyarakat, image hotel melati di masyarakat, kebiasaan masyarakat dalam memilih hotel maupun mempertimbangkan kekhasan dari hotel melati.

Dengan demikian dapat disimpulkan bahwa hipotesis empat b (H4b) yang menyatakan semakin kuat budaya semakin kuat pengaruh orientasi pasar terhadap kinerja pemasaran tidak terbukti dan tidak didukung oleh fakta.

\section{SIMPULAN, SARAN DAN KETERBATASAN}

\section{Simpulan}

Berdasarkan hasil pembahasan dapat dikemukakan simpulan sebagai berikut:

1) Indikator orientasi kewirausahaan yaitu inovatif, proaktif dan keberanian mengambil resiko memberikan kontribusi terhadap orientasi kewirausahaan. Orientasi kewirausahaan berpengaruh tidak signifikan terhadap kinerja pemasaran. Lemahnya orientasi kewirausahaan menjadikan pemilik/manajer hotel melati di Jawa Timur tidak cukup inovatif, proaktif dan kurang berani mengambil resiko dalam mencari peluang-peluang usaha baru.

2) Pemilik/manajer hotel melati di Jawa Timur telah menggunakan pandangan pemasaran baru yaitu orientasi pasar. Indikator orientasi pasar yaitu orientasi pada pelanggan, orientasi pada pesaing, koordinasi antar fungsi, fokus jangka panjang dan profitabilitas. Orientasi pasar terbukti berpengaruh positif terhadap kinerja pemasaran Hotel melati yang berorientasi pasar dalam pengelolaannya akan lebih memusatkan perhatian pada pelanggan, hal ini berarti akan menuntun pemilik/manajer hotel melati lebih memusatkan upaya mengikat pelanggan potensial dalam upaya meningkatkan tingkat hunian kamar.

3) Gejolak pasar sebagai variabel moderator memperlemah pengaruh orientasi kewirausahaan dan orientasi pasar terhadap kinerja pemasaran. Hal ini mengindikasikan bahwa gejolak pasar tidak memiliki efek moderasi pengaruh orientasi kewirausahaan dan orientasi pasar terhadap kinerja pemasaran.

Gejolak Pasar Dan Budaya Sebagai Moderasi (Ayun Maduwinarti) 
4) Budaya merupakan moderasi semu pengaruh orientasi kewirausahaan terhadap kinerja pemasaran. Koefisien interaksinya positif, sehingga budaya sebagai moderasi memperkuat pengaruh orientasi kewirausahaan terhadap kinerja pemasaran. Orientasi kewirausahaan ternyata secara langsung tidak mampu meningkatkan kinerja pemasaran, akan tetapi setelah di moderasi dengan budaya maka memperkuat pengaruh orientasi kewirausahaan terhadap kinerja pemasaran. Artinya pemilik/manajer hotel melati dalam melaksanakan orientasi kewirausahaan harus mempertimbangkan budaya masyarakat agar mampu meningkatkan kinerja pemasaran.

\section{Saran}

\section{Untuk para pemilik/manajer hotel}

a. Dengan memperhatikan Orientasi Kewirausahaan ternyata secara langsung tidak mampu meningkatkan kinerja pemasaran, tetapi setelah di moderasi dengan budaya maka memperkuat pengaruh orientasi kewirausahaan terhadap kinerja pemasaran. Pemilik/manajer hotel melati hendaknya dalam melaksanakan orientasi kewirausahaan (inovatif, proaktif dan keberanian mengambil resiko) mempertimbangkan budaya masyarakat, agar implikasi orientasi kewirausahaan mampu meningkatkan kinerja pemasaran.

b. Dengan adanya bukti-bukti empirik bahwa orientasi pasar berpengaruh terhadap kinerja pemasaran, maka dalam pengelolaan hotel melati kegiatan melakukan orientasi pasar merupakan kegiatan yang sebaiknya tetap dilakukan apabila pemilik/manajer hotel melati ingin meningkatkan kinerja pemasarannya.

c. Pemilik/manajer hotel melati harus peka terhadap budaya serta melakukan upaya untuk melakukan tindakan adaptasi dan mampu memanfaatkan perubahan budaya sebagai peluang bukan sebagai ancaman. Pemilik/manajer hotel melati hendaknya berupaya terus menerus mengenali pergeseran nilai budaya agar bisa dimanfaatkan untuk menemukan produk dan jasa baru yang bisa diterima tamu hotel.

\section{Untuk Penelitian Lebih Lanjut}

a. Bagi para peneliti lanjutan dapat melakukan penelitian gejolak pasar dan budaya sebagai moderasi pengaruh orientasi kewirausahaan dan orientasi pasar terhadap kinerja pemasaran, dengan menambah indikator-indikator kinerja pemasaran, misalnya target profit yang diinginkan, return on investment atau lamanya tamu tinggal di hotel.

b. Para peneliti lanjutan dapat melakukan penelitian yang sama di hotel berbintang, sehingga bisa membandingkan apakah gejolak pasar dan budaya sebagai moderasi bisa memperkuat atau memperlemah kinerja pemasarannya.

\section{Keterbatasan}

Beberapa temuan telah berhasil digali dalam penelitian ini yang berkenaan dengan bisnis hotel melati, akan tetapi penelitian ini juga memilki keterbatasan yaitu: 
1. Instrumen penelitian yang berupa kuesioner digunakan untuk menggali persepsi manajemen, sehingga peneliti kurang mampu mengontrol sepenuhnya kejujuran responden dalam memberikan opsi jawaban sesuai dengan kondisi senyatanya.

2. Seperti pada penelitian cross-sectional lainnya, kelemahan yang melekat yaitu bahwa data yang diperoleh hanya pada waktu tertentu sehingga kurang bisa mengakomodasi generalisasi kesimpulan secara akurat.

\section{DAFTAR PUSTAKA}

Amstrong, G. dan K. Philip. 2000. Marketing An Introduction. Fifth Edition. Prentice Hall, Upper Saddle River, New Jersey.

Augusto, M. dan F. Coelho. 2006. Market Orientation and New-to-the-world Products: Exploring the Moderating Effects of Innovativeness, Competitive Strength, and Environment Forces, Industrial Marketing Management 1(15).

Baker, W., dan J.M. Sinkula. 1999. Learning Orientation, Market Orientation and Innovation: Integrating and Extending Models of Organizational Performance. Journal of Market Focused Management 4: 295-308.

. 2009. The Complementary Effects of Market Orientation and Entrepreneurial Orientation on Profitability in Small Businesses, Journal of Small Business Management 47(4): 443-464.

Bhuian, S., N. B. Mengue, dan S. J. Bell. 2002. Just Entrepreneurial Enough: The Moderating Effect of Entrepreneurship on the Relationship between Market Orientation and Performance, Journal of Business Research 58: 9-17.

Biro Pusat Statistik. 2009. Jawa Timur Dalam Angka, Jawa Timur: Propinsi Jawa Timur.

Covin, J.G. dan D.P. Slevin. 1989. Stategic Management of Small Firms in Hostile and Benign Environments. Strategik Management Journal 10(1): 75-87.

Covin, J. G. 1991. Entrepreneurial Versus Conservative Firms a Comparison or Strategies and Performance, Journal of Management Study 28(4): 9-462.

Dilts dan Prough. 2001. Environmental Change, Strategik Choise and Entrepreneurial Orientation: The Case of the Travel Services Industry. Services marketing Quarterly 22(1).

Gejolak Pasar Dan Budaya Sebagai Moderasi (Ayun Maduwinarti) 
Dinas Kebudayaan dan Pariwisata Provinsi Jawa Timur. 2011. Pariwisata Jawa Timur Dalam Angka 2009.

Ferdinand, A. 2006. Metode Penelitian Manajemen, Pedoman Penelitian Untuk Penulisan Skripsi, Teses dan Disertasi Ilmu Manajemen, Edisi 2, Seri Pustaka, Fakultas Ekonomi Universitas Diponegoro, Semarang.

Frishammar, J. dan A.H. Sven. 2007. The Role of Market Orientation and Entrepreneurial Orientation for New Product Development Performance in Manufacturing Firms. Technology Analysis dan Strategik Management 19(6): 765-788.

Geletkanycz, M.A. 1997. The Salience of 'Culture's Consequences': The Effects of Cultural Values on Top Executive Commitment to the Status Quo. Strategic Management Journal 18(8): 615-634.

Gima, A., Kwaku dan Ko.Anthony. 2001. An Empirical Investigation of the Effect of Market Orientation and Entrepreneurship Orientation Alignment on Product Innovation. Organization Science 12(1): 54-74.

Grennly, G.E. 1995. Market Orientation and Company Performance: Empirical Evidence from UK. Companies. British Journal of Management 6: 1-13.

Hirsch, R.D. dan Michael P.Peter. 1992. Entrepreneurship, Strating, Developing and Managing a New Entreprise. Second Edition. Irwin. USA.

Idrus, MS. 2007. Metode Penelitian Ilmu-Ilmu Sosial, Pendekatan Kualitatif dan Kuantitatif. UII Press. Yogyakarta

Jawaroski, B dan A.K. Kohli. 1993. Marketing Orientation: Antecendents and Consequences, Journal of Marketing 57: 53-70.

Jogaratnam, G., E. Ching dan Y. Tse. 2006. Entrepreneurial orientation and the structuring of organizations Performance evidence from the Asian hotel industry. International Journal of Contemporary Hospitality Management 18(6): 454-468.

Kohli, A.K. dan B. Jaworski. 1990. Market Orientation: The Construct, Research Propositions, and Managerial Implication. Journals of Marketing 54(2): 118.

Malholtra, N.K. 2004. Marketing Research, An Applied Orientation. Fourth Edition. International Edition. Prentice Hall International, Inc. New Jersey. 
Matsuno, K. dan J.T. Mentzer. 2000. The Effects of Strategy Type on the Market Orientation-Performance Relationship. Journal of Marketing 64: 1-16.

Miller, D. 1983. The Correlates of Entrepreneurship in Three Types of Firms, Management Science 29: 770 - 791.

Miller, D., dan P. N. Friesen. 1983. Strategy-making and environment: The third link. Strategic Management Journal 4: 221-235.

Naldi, L., N. Mattias, S. Karin dan J. Wiklund. 2007. Entrepreneurial Orientation, Risk Taking, and Performance in Family Firms. Family Business Review, XX(1).

Narver, J.C. dan S.F. Slater. 1990. The Effect of Market Orientation on Business Profitability. Journal of Marketing, October 1990: 20-35.

Ngamkroeckjoti, C. dan M. Speece. 2008. Technology Turbulence and Environmental Scanning in Thai Food New Product Development. Asia Pacific Journal of Marketing and Logistic 20(4): 413-432.

Pelham, M.A. 2000. Market Orientation and Other Potential Influences on Performance in Small and Medium-Sized Manufacturing Firms, Journal of Small Business Management 29(January) 48-67.

Pelham, M.A. dan T. Wilson. 1996. A Long Intudinal Study of the Impact of Market Structure, Firms Structure, Strategy, and Market Orientation Culture on Dimensions of Small Firm Performance. Journal of The academy of Marketing Science.

.1997. Mediating Influences on the Relationship Between Market Orientation and Profitability in Small Industrial Firms. Journal of Marketing Theory and Practice 5 (Maret): 55-76.

Perrelault, Jr., D. William dan E.J. Mc. Carthy. 1999. Basic Marketing Global Managerial Approach. Irwin McGraw-Hill. Boston.

Priyanto, 2004. Pengaruh Lingkungan Eksternal, Kewirausahaan dan Kapasitas Manajemen Terhadap Kinerja Usaha Tani: Studi Empiris pada Petani Tembakau di Jawa Tengah. Disertasi S3 PPS Universitas Brawijaya. Tidak Dipublikasikan.

Raju, P.S., C.L. Subbash dan Y.P. Gupta. 1995. Market Orientation and Performance in Hospital Industry, Journal of Health Care Marketing 15(5): 34-41.

Gejolak Pasar Dan Budaya Sebagai Moderasi (Ayun Maduwinarti) 
Renko M., A. Carsrud dan M . Brannback. 2009. The Effect of a Market Orientation, Entrepreneurial Orientation, and Technological Capability on Innovativeness: A Study of Young Biotechnology Ventures in the United States and in Scandinavia. Journal of Small Business Management 47(3): 331-369.

Slater, S. F., dan J. C. Narver. 1994. Does Competitive Environment Moderate the Market Orientation-Performance Relationship? Journal of Marketing 58: 4655.

.1995. Market Orientation and The Learning Organization. Journal of Marketing 59(3): 63-74.

Subramanian, R., Kumar dan S. Karen. 2009. The Relationship Between Market Orientation And Performance under Different Environmental Conditions: The Moderating Effect Of The Top Management Team's Risk Taking Behavior, Academy of Strategik Management Journal 8: 121-135.

Sulastiyono, Agus. 2006. Manajemen Penyelenggaraan Hotel, Seri Manajemen Usaha Jasa Pariwisata Dan Akomodasi, Alfabeta, Bandung.

Tzokas, N., S. Carter dan P. Kyriazopoulos. 2001. Marketing and Entrepreneurial Orientation in Small Firms. Enterprise and Innovation Management Studies 2(1): 19-33

Undang-Undang Republik Indonesia Nomor 10 Tahun 2009 tentang Kepariwisataan.

Varadarajan, P.R. dan J.S. Chandran. 1999. Marketing Strategy: An Assessment of the State of Field and Outlook. Academy of Marketing Science Journal 27(2): 120.

Vitale, R.,J. Giglierano dan M. Miles. 2002. Entrepreneurial Orientation, Market Orientation and Performance in Established and Start Up Firms.

Wiklund, J. 1999. The Sustainability of The Entrepreneurial Orientation-Performance Relationship. Entrepreneurship Theory and Practice.

Yuan Li, Y. Zhao Tan J dan Y. Liu. 2008. Moderating Effects of Entrepreneurial Orientation on Market Orientation-Performance Linkage: Evidence from Chinese Small Firms. Journal of Small Business management 46(1): 113-115.

Zyl, H.J.C. dan B.M. Helm. 2007. Exploring a conceptual model, based on the combined effects of entrepreneurial leadership, market orientation and relationship marketing orientation on South Africa's small tourism business performance. S.Afr.J.Bus.Manage 38(2): 17 